\title{
Gene trap capture of a novel mouse gene, jumonji, required for neural tube formation
}

\author{
Takashi Takeuchi, ${ }^{1}$ Yukiko Yamazaki, Yuko Katoh-Fukui, Reiko Tsuchiya, Shunzo Kondo, \\ Jun Motoyama, and Toru Higashinakagawa
}

Mitsubishi Kasei Institute of Life Sciences, Machida, Tokyo 194, Japan

\begin{abstract}
A mouse mutation, termed jumonii (jmj), was generated by a gene trap strategy. Expression of the trapped gene (jmj gene), as monitored by $\mathrm{X}$-gal staining, was detected predominantly at the midbrain-hindbrain boundary and in the cerebellum, depending on the stage of development. All embryos homozygous for the jmj mutation died before embryonic day 15.5. Some, but not all, of the homozygotes developed an abnormal groove in a region just anterior to the midbrain-hindbrain boundary on the neural plate at embryonic day 8-8.5 and showed a defect in neural tube closure in the midbrain region. Analyses of $j m j$ cDNA revealed that the $i m j$ gene is novel, conserved among vertebrates, and disrupted by vector insertion in the $j m j$ homozygotes. The amino acid sequence deduced from the cDNA shared a portion of significant homology with human retinoblastoma-binding protein RBP-2 and with a putative protein encoded by human gene XE169 that escapes $\mathrm{X}$-chromosome inactivation. These results suggest that $j \mathrm{mj}$ gene is essential for normal morphogenesis of the neural tube.
\end{abstract}

[Key Words: Gene trap; insertional mutagenesis; embryonic stem cells; neurulation]

Received December 28, 1994; revised version accepted April 3, 1995.

Mutant organisms that exhibit abnormal and sometimes intriguing phenotypes have contributed enormously to our understanding of heredity. Historically, mutations have provided links between genes and biological phenomena, offering clues to elucidating the cellular and molecular mechanisms underlying their phenotypes. In higher animals such as mammals, identifying genes responsible for mutant phenotypes, forward genetics, has increasingly advanced during the past decade but still remains difficult because of the complexity of the mammalian genome and the labor intensive nature of the effort required. As an alternative approach, the process termed reverse genetics has been used to explore structure-function relationships of individual genes. With the advent of modern methods of gene targeting, involving homologous recombination in mice, have come major advances in our understanding of the function of numerous genes of importance in normal development and in diseases.

One methodology, called gene trap, represents a versatile strategy by which genes that control developmental events can be captured and identified while at the same time corresponding mutants can be produced (Gossler et al. 1989; Friedrich and Soriano 1991; Skarnes et al. 1992; Chen et al. 1994; DeGregori et al. 1994). This approach combines features of both forward and reverse genetics and identification of interrupted trapped genes

${ }^{1}$ Corresponding author. is usually straightforward and direct as compared with classical genetics.

While in search of genes required for morphogenesis of the brain, we improved the efficiency of the gene trap methodology in several respects, and we established a mutant mouse strain displaying an intriguing defect in neurulation. In this study homozygous fetal mice died in utero, and a significant proportion of the homozygotes showed abnormal groove formation on the neural plate and a defect in neural tube closure. We named this mutation "jumonji," because the morphology produced by the normal neural groove and abnormal grooves resembles a cross (jumonji is literally translated as cruciform in Japanese). The trapped gene, presumed to be responsible for these phenotypes, encodes a protein that is significantly homologous to the human retinoblastomabinding protein RBP- 2 and to a putative protein encoded by human gene XE169, which escapes X-chromosome inactivation. These results, taken together with the fact that the trapped gene is conserved among vertebrates, suggest that the trapped gene is required for normal morphogenesis of the neural tube.

\section{Results}

Trap vector and trapped cell screening

A trap vector, designated TV2, possessing several features appropriate for the gene trap strategy, was con- 
structed by conventional methods (Fig. 1A). TV2 has a neomycin-resistant $\left(n e o^{\mathrm{r}}\right)$ gene for selection against G418 and a lacZ gene for monitoring the expression of the trapped gene by X-gal staining. An internal ribosome entry site (IRES) derived from encephalomyocarditis virus was inserted between $n e o^{\mathbf{r}}$ and $l a c Z$ to enable the dicistronic expression of two genes (Jang et al. 1988; Kim et al. 1992). Kim et al. (1992) showed that lacZ was expressed throughout the entire chimeric embryo derived from ES cells transfected with phosphoglucokinase-1

A

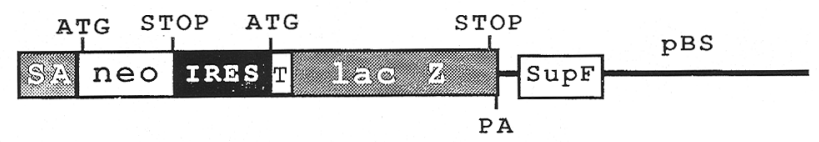

B

a)

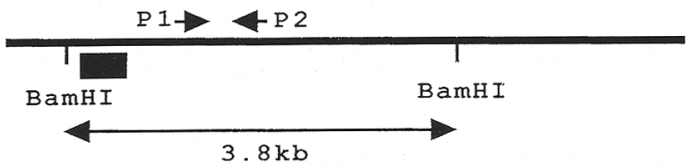

b)

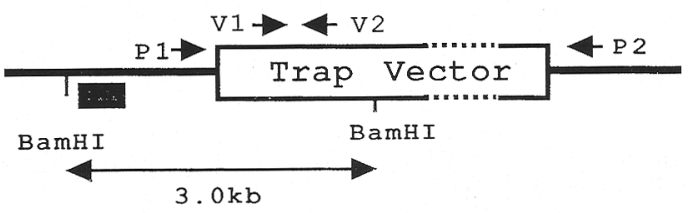

c)

\begin{tabular}{|l|c||ccc|}
\hline PCR & Southern & Wild & Ht & Hm \\
\hline P1 $\leftrightarrow$ P2 & $3.8 \mathrm{~kb}$ & + & + & - \\
V $\leftrightarrow$ V2 & $3.0 \mathrm{~kb}$ & - & + & + \\
\hline
\end{tabular}

C
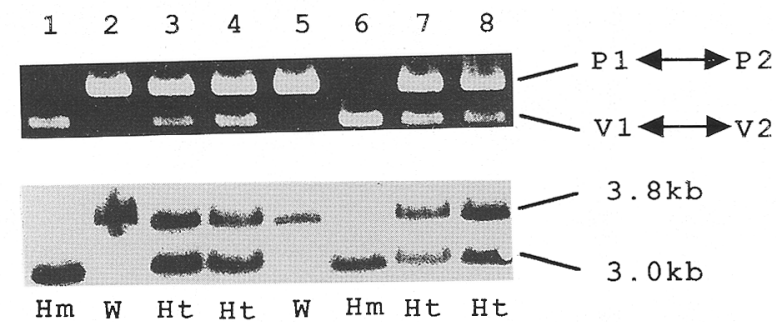

Figure 1. Trap vector and genotype analysis. $(A)$ Trap vector, TV2. (SA) Zfp-40 splicing acceptor; (neo) neo gene; (IRES) encephalomyocarditis virus internal ribosome entry site; (T) SV40 nuclear transporting signal; (Sup F) E. coli supF tRNA gene; (ATG) initiation codon; (Stop) termination codon; (PA) SV40 polyadenylation signal; (pBS) plasmid Bluescript (Stratagene). $(B)$ The schema for identification of genotypes. $|a|$ Wild-type allele; $(b)$ trapped allele; $(c)$ predicted pattern. $(\mathrm{P} 1, \mathrm{P} 2, \mathrm{~V} 1, \mathrm{~V} 2)$ PCR primers. PCR with $\mathrm{P} 1-\mathrm{P} 2$ and with $\mathrm{V} 1-\mathrm{V} 2$ recognize wildtype allele and trapped allele, respectively. The region targeted by $\mathrm{P} 1-\mathrm{P} 2$ in the trapped allele is not amplified because its length is too great for PCR. (1) Probe for Southern blot analysis that recognizes the $3.8-\mathrm{kb}$ BamHI fragment of the wild allele and the $3.0-\mathrm{kb}$ fragment of the trapped allele. (Wild) Wild type; $(\mathrm{Ht})$ heterozygous; $(\mathrm{Hm})$ homozygous. $(C)$ Examples of PCR analysis (top) and Southern blot analysis (bottom) of genotypes. (Lanes 1-8) Results of individual embryos. (W) Wild type.
promoter-neor-IRES-lac $Z$ vector. This result suggests that there is no tissue specificity for IRES function.

Because TV2 has no promoter sequences, only trapped cells can survive in media containing G418. A splicing acceptor sequence placed at the $5^{\prime}$ terminus of the $n e o^{r}$ gene is expected to enhance the trapping efficiency (Gossler et al. 1989). The sequence for nuclear transporting peptide derived from SV40 large T gene was placed at the $5^{\prime}$ terminus of the $l a c Z$ sequence. This sequence is expected to concentrate $l a c Z$ products in the nucleus (Kimura et al. 1994; M. Tanaka, pers. comm.) and facilitates detection of cells expressing trapped genes. The supF and $\mathrm{pBS}$ sequences in Figure 1A are for the purpose of recovering the trapped gene by plasmid rescue and are irrelevant to the present study. A total of $6 \times 10^{7} \mathrm{E} 14$ embryonic stem (ES) cells were transfected with the TV2 trap vector in three independent experiments, and 44 G418-resistant colonies were recovered. Among them, 41 colonies $(93.2 \%)$ were stained positively with X-gal, showing that IRES functioned as expected. As to why three colonies were X-gal negative, two possibilities may exist: (1) The promoter of the trapped gene was so weak that lacZ expression could not be detected, and (2) the lac $Z$ gene was damaged during introduction into ES cells.

\section{lacZ expression in chimeric embryos} and the establishment of $a$ jmi mouse

Nineteen X-gal positive cell lines were selected and each was processed for production of chimeric embryos. Expression patterns of lacZ were monitored by wholemount X-gal staining of the embryos. A chimeric embryo obtained from a gene-trapped cell line, B6, was of special interest because of its characteristic lac $Z$ expression in a restricted region of the neural tube in the 10.5 day embryo (E10.5) and also in the cerebellum of neonates. A significant proportion of $F_{1}$ progeny resulting from mating B6-derived chimeric male mice to $\mathrm{Balb} / \mathrm{cA}$ female mice was found by Southern blotting to possess the trapped allele. We named this mouse line as jumonji (jmj) because of its characteristic phenotype associated with homozygotes described later. im $i$ heterozygotes appeared phenotypically normal.

\section{lacZ expression patterns of jmj heterozygotes}

lacZ expression patterns in embryos (E8.0-E12.5) and brains (E14.5-postnatal day 14, P14) of $j m j$ heterozygotes were examined by whole-mount X-gal staining. Strong expression was detected at the midbrain-hindbrain boundary (Fig. 2A-C) whereas relatively weak expression was seen ubiquitously throughout developmental stages. Expression at the midbrain-hindbrain boundary was observed as early as E8.5, with some additional weak expression in the head region (Fig. 2A). In the E9.5 embryo, this expression increased in intensity, forming a ring-shape structure (Fig. 2B). Conspicuous expression of lac $Z$ was also noted at this stage in the primitive phar- 

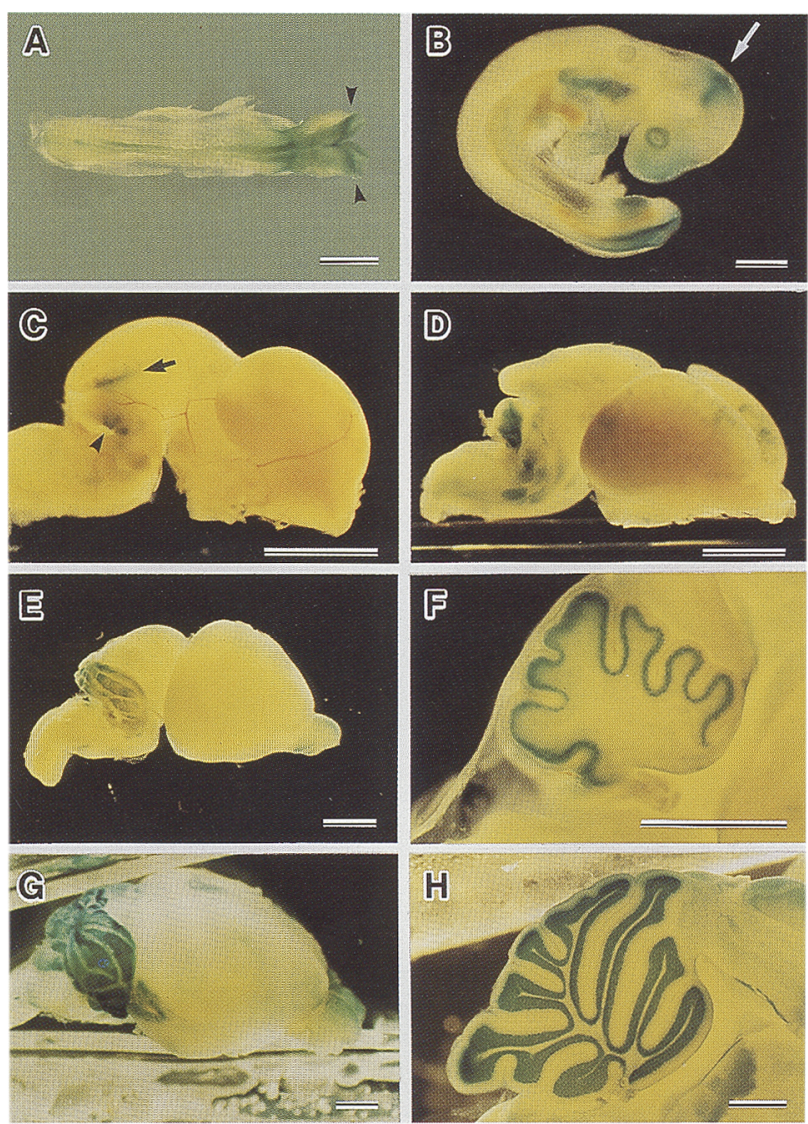

Figure 2. lac $Z$ expression patterns in heterozygous mice revealed by X-gal staining. $(A) \mathrm{E} 8.5$, dorsal view of the whole embryo; arrowheads show expression in future midbrain-hindbrain boundary. $(B)$ E9.5, lateral view of whole embryo; arrow shows expression at midbrain-hindbrain boundary. $(C-E, G)$ Lateral view of excised brain. $|C|$ E14.5; arrow and arrowheads show expression at midbrain-hindbrain boundary and in cerebellum, respectively; $(D)$ E16.5; $(E) \mathrm{P} 2 ;(G) \mathrm{P} 14 .(F, H)$ Sagittal section of cerebellum of $E$ and $G$ with a razor, respectively. Scale bars, $(A, B) 500 \mu \mathrm{m}_{;}(C-E, G) 2 \mathrm{~mm} ;(F, H) 1 \mathrm{~mm}$.

ynx, the bulbous cordis of the heart, and around the posterior neuropore in the tail.

lac $Z$ expression at the midbrain-hindbrain junction persisted until E14.5 (Fig. 2C) but became undetectable after E16.5 (Fig. 2D,E,G). In contrast, expression the in cerebellum was first detected at E14.5 in its lateral regions (Fig. 2C) and spread to the whole cerebellum at E16.5 (Fig. 2D). On P2, expression was confined to Purkinje cells (Fig. 2F). During P2-P14, an increasing number of cells in the internal granular layer were stained with $\mathrm{X}$-gal until $\mathrm{lac} Z$ expression was detected in all granule cells at $\mathrm{P} 14$ (Fig. 2H). Thus, the lacZ expression profile of granule cells appeared to coincide with the timing of their migration and functional differentiation. In the forebrain, lacZ expression was also detected at several regions.

\section{imj homozygotes show embryonic lethality}

Analysis of the $1 a c Z$ expression patterns suggested that the $i m j$-trapped gene is involved in the formation of the neural tube and development of the cerebellum. Because no apparent abnormality was associated with heterozygous mice, the phenotype of imj homozygotes was examined. Genotypes of offspring derived from heterozygous parents were determined by polymerase chain reaction (PCR) or Southern blot analysis (Fig. 1B,C; Table 1). For this purpose, sequences flanking the trap vector insertion site were amplified by the PCR-cassette method (see Materials and methods). Using the amplified product as a probe, a genomic library was screened to obtain a genomic clone containing the corresponding wild-type gene.

There were no homozygotes among the genotypes of pups derived from heterozygous parents (Table 1). The ratio of wild type, heterozygotes, and homozygotes, $\sim 1$ : 2:0, indicates that $i m j$ homozygotes die before birth. Live homozygous embryos were found during gestation (Table 1), but the number of dead embryos, first detected at E10.5, increased as gestation proceeded until almost all of the homozygotes died by E15.5 (Table 2). Severe necrosis prevented the identification and recovery of some of the resorbed embryos. All of the E14.5 homozygous embryos recovered showed severe edema in the large area of the back (Fig. 3). It is plausible to assume that the edema is involved in the lethality. However, we could not detect any apparent histological abnormalities associated with edema, such as defects in the circulation system or in the kidney.

A significant number of the homozygous embryos showed a neural tube defect (NTD) around the midbrain region (Fig. 4) or abnormal groove formation (Figs. 5 and 6). These abnormal phenotypes were limited, almost exclusively, to homozygotes (Table 2), although there were rare cases of dead or NTD embryos among wild-type and heterozygous offspring. We presume that the latter cases were spontaneous.

\section{Abnormal groove formation in the neural plate of jmi homozygotes at E8-8.5}

At E8-8.5, 5 of 13 homozygous embryos $(38.5 \%)$ developed abnormal grooves (Table 2; Figs. 5 and 6). Figure 5B shows a typical example observed at E8. The normal neural groove and ectopic grooves intersect to form a cross. At E8.5, the head neural plate of abnormal homozygotes exhibited a prominent flexure (Fig. 6B). At this stage, the future midbrain-hindbrain boundary can be recognized (Fig. 6E, arrowhead). lac $Z$ expression was detected in the vicinity of the midbrain-hindbrain boundary in heterozygotes (Fig. 6C, arrowhead). In homozygotes, expression was even stronger in the same region of the embryo (Fig. 6D, arrowhead). Therefore, the location of the abnormal grooves appeared to be just anterior to the midbrain-hindbrain boundary.

Transmission electron microscopy of the cells comprising the abnormal grooves did not reveal any ultrastructural abnormality as compared with heterozygotes (Fig. 5C, D). The abnormal grooves had a cleft-like shape, and, similar to heterozygotes, the neuroepithelial cells were characterized by tight junctions at their apices and 
Table 1. Genotypes of offspring derived from heterozygous parents

\begin{tabular}{|c|c|c|c|c|c|c|}
\hline \multirow[b]{2}{*}{ Stage } & \multirow{2}{*}{$\begin{array}{l}\text { Litters } \\
\text { (no.) }\end{array}$} & \multirow{2}{*}{$\begin{array}{l}\text { Embryos a } \\
\text { (no.) }\end{array}$} & \multicolumn{4}{|c|}{ Genotype $^{b}$} \\
\hline & & & wild type & heterozygote & homozygote & N.D. \\
\hline \multicolumn{7}{|l|}{ Embryo } \\
\hline E8.0-8.5 & 4 & 43 & $5(11.6)$ & $25(58.4)$ & $13(38.5)$ & $0(0)$ \\
\hline E8.5-9.5 & 6 & 66 & $18(27.5)$ & $33(50.4)$ & $15(22.7)$ & $0(0)$ \\
\hline E10.5-11.5 & 6 & 80 & $23(28.8)$ & $37(46.3)$ & $12(15.0)$ & $8(10)$ \\
\hline E12.5-13.5 & 5 & 51 & $18(35.3)$ & $22(43.1)$ & $8(15.7)$ & $3(6)$ \\
\hline E14.5-15.5 & 5 & 47 & $17(36.2)$ & $20(42.6)$ & $6(12.8)$ & $4(8.5)$ \\
\hline Total & 31 & 288 & $81(28.1)$ & $137(47.6)$ & $53(18.4)$ & $15(5.2)$ \\
\hline \multicolumn{7}{|l|}{ Postnatal (days) } \\
\hline P28-40 & 15 & 94 & $33(35.1)$ & $61(64.9)$ & $0(0)$ & $0(0)$ \\
\hline
\end{tabular}

${ }^{a}$ All numbers contain resorbed embryos.

bNumbers in parentheses are percentages of offspring carrying each genotype. (N.D.) Genotypes could not be determined because of necrosis.

an underlying basement membrane. No abnormalities were observed in the number of mitotic or dead cells or in the number, morphology, or distribution of mesenchymal cells beneath neural plate.

\section{Neural tube defect in imj homozygotes}

In wild-type mice, the neural tube fuses first at the cervical/hindbrain boundary during the seven-somite stage, and closure of the neural tube then spreads in both the cranial and caudal directions. Second and third de novo fusions occur at the posterior and anterior sites of the forebrain, respectively. Closure spreads from these sites and is completed in the hindbrain (MacDonald et al. 1989; Sakai 1989/. The profile of neural tube closure in $i m j$ heterozygous and homozygous mice was examined and compared with that of wild-type mice. No appreciable difference was noted between $i m i$ heterozygous and wild-type embryos. In contrast, normal $(40.0 \%)$ and abnormal types $(60.0 \%)$ were observed among 15 homozygous embryos (Table 2). Figure 7, E-H, show abnormal homozygotes, which displayed delayed closure as well as failure of fusion at the posterior site of the forebrain even at the 21-somite stage. In this casc, fusion at the anterior site of the forebrain occurred and closure spread from this site but was apparently arrested before completion (Fig. $7 \mathrm{H}$ ). We conclude that NTD of $i m j$ homozygotes resulted from a defect in neural tube fusion at the posterior site of the forebrain.

\section{Isolation of jmj cDNA}

Southern blot analysis of DNA extracted from B6-ES cells suggested that a complete copy of the trap vector followed by at least four copies, each missing neo ${ }^{\mathrm{r}}$, were integrated in tandem into a single site (data not shown). Northern blot analysis of RNA from B6-ES cells revealed a single band of $6 \mathrm{~kb}$ using either the neo or lac $Z$ gene as a probe (data not shown). From these results, it was concluded that the most $5^{\prime}$ copy of trap vector functioned as a selectable marker and as a reporter, and only the single type of fusion transcript containing both the neor and lac $Z$ sequences was produced in trapped B6-ES cells.

The trapped gene of B6-ES cells and its product were designated $i m i$ gene and $i m j$ protein, respectively. The 5-kb cDNA clone for the imi gene (imi cDNA) was isolated by first applying the 5' RACE (rapid amplification of cDNA ends) method to fusion RNA extracted from B6-ES cells (Frohman et al. 1988). This was followed by four successive downstream walks along the cDNA library (see Materials and methods). The imi cDNA potentially encodes a polypeptide of 1234 amino acids (Fig. 81 , and the molecular mass of this polypeptide is calculated to be $137.5 \mathrm{kD}$. The first ATG (position 211) of the

Table 2. Abnormal phenotypes during gestation

\begin{tabular}{|c|c|c|c|c|c|c|}
\hline \multirow[b]{2}{*}{ Stage } & \multicolumn{3}{|c|}{ Wild type + Heterozygote ${ }^{a}$} & \multicolumn{3}{|c|}{ Homozygote $^{a}$} \\
\hline & normal & $\begin{array}{c}\text { abnormal } \\
\text { head }^{b}\end{array}$ & dead & normal & $\begin{array}{c}\text { abnormal } \\
\text { head }^{b}\end{array}$ & dead \\
\hline E8.0-8.5 & 100 & 0 & 0 & 61.5 & 38.5 & 0 \\
\hline E8.5-9.5 & 100 & 0 & 0 & 40.0 & 60.0 & 0 \\
\hline E10.5-11.5 & 95.0 & 1.7 & 3.3 & 41.7 & 33.3 & 25.0 \\
\hline E12.5-13.5 & 98.0 & 0 & 2.0 & 37.5 & 12.5 & 50.0 \\
\hline E14.5-15.5 & 100 & 0 & 0 & 0 & 16.7 & 83.3 \\
\hline
\end{tabular}

aNumbers show percentage of each phenotype in total number of embryos of Table 1.

${ }^{b}$ Abnormal groove formation (E8-8.5), abnormal closure (E8.5-9.5), or NTD (E10.5-E15.5). 

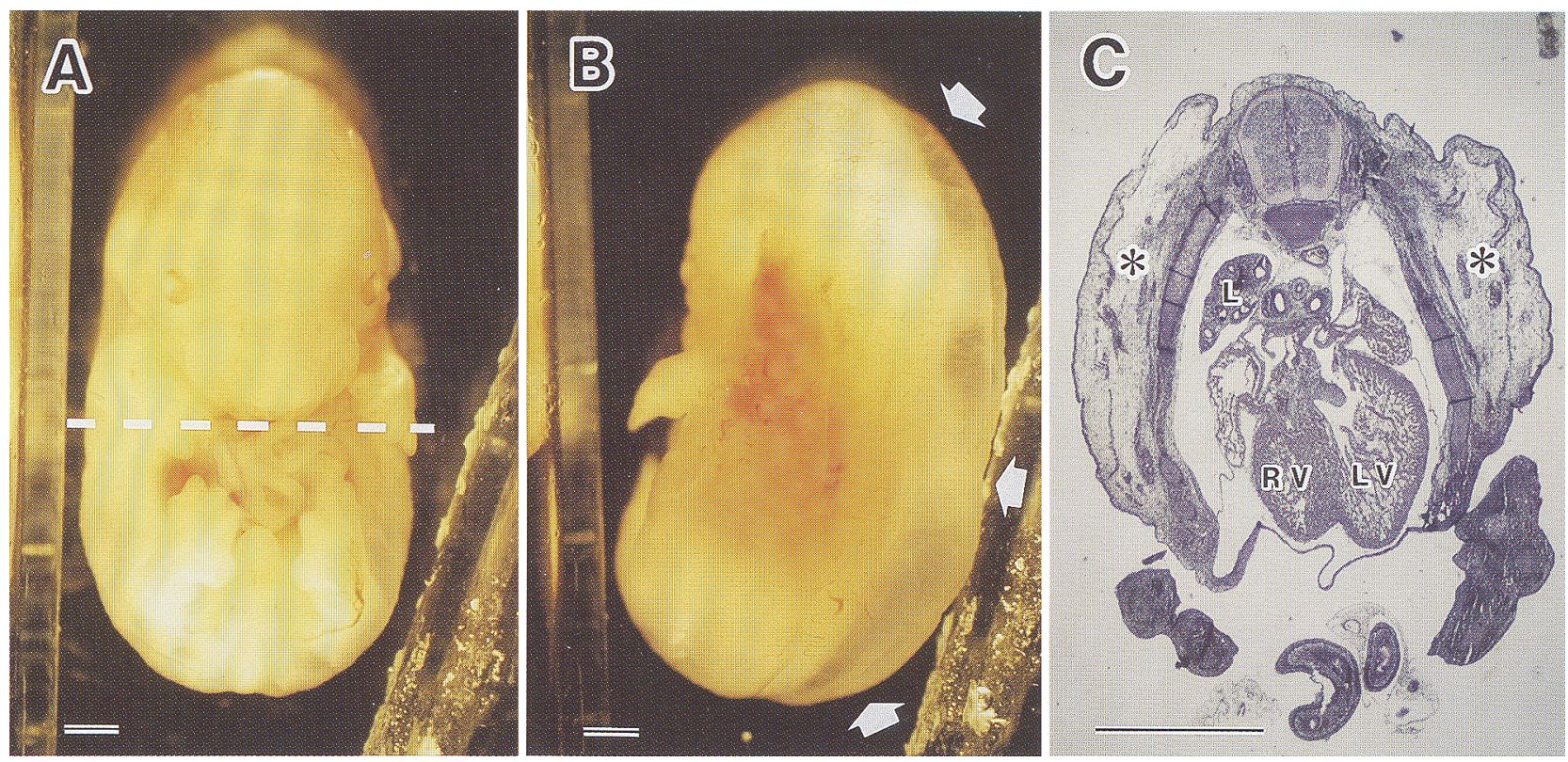

Figure 3. Edema observed in E14.5 imj homozygotes. $(A)$ Ventral view. The tail was cut for genotyping. Broken line shows the level of the section in $C$. $(B)$ Dorsal view of $A$. Arrow shows severe edema observed in large area of the back. $(C)$ The transverse section of $A$. Asterisks ( $\left.{ }^{*}\right)$ show edema in the dermis. (L) lung; (LV) left ventricle; (RV) right ventricle. Scale bar, $1 \mathrm{~mm}$.

open reading frame represents a good candidate for the initiation codon, because an in-frame stop codon is found in the upstream region (TAA, double underlined at position 160), and the sequence around this ATG is in a favorable context for translation initiation (Kozak 1991). The junction between the $i m j$ cDNA and $n e o^{\mathrm{r}}$ of the trap vector in making fusion mRNA is between positions 255 and 256 (Fig. 8, arrowhead).

Amino acid sequences deduced from $i m j$ cDNA were compared with those translated from DNA sequences compiled in the EMBL and GenBank data bases. This search revealed two regions $(A, 541-780$; and B, 8161107 in $\mathrm{im} j$ protein) (Fig. 8, underlined) of significant homology with human retinoblastoma binding protein- 2
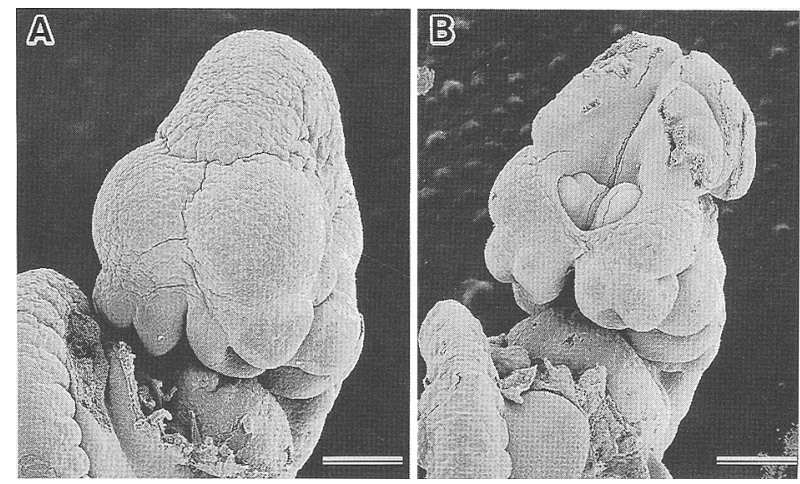

Figure 4. Neural tube defect of $j m j$ embryos. Scanning electron micrographs of E1 1.5 embryos derived from the same litter. $(A)$ heterozygote; $(B)$ homozygote. Scale bar, $500 \mu \mathrm{m}$. The homozygote has a ND in the midbrain region.
(RBP-2) (Fattaey et al. 1993) and with a putative protein encoded by human gene XE169, which escapes X-chromosome inactivation (Wu et al. 1994) (Table 3). Significance is shown by $z$ value (Lipman and Pearson 1985). Although the overall homology between RBP-2 and the $X E 169$ protein is high $(48.1 \%)$, the homology in regions corresponding to $\mathrm{A}$ and $\mathrm{B}$ of the $i m j$ protein is considerably higher $(57.7 \%$ and $82.6 \%$, respectively) (Table 3$)$. Region B exhibited a significant homology with proteins encoded by two mouse genes, Smcx and Smcy (Agulnik et al. 1994a,b). Smcx is presumed to be a mouse homolog of XE169 (Agulnik et al. 1994b). Smcx and Smcy are highly homologous to each other. It is not known whether region A exists in Smcx and Smcy proteins, because only partial sequences were reported for the $S m c x$ and Smcy genes (Agulnik et al. 1994a,b). Aside from possible phosphorylation and glycosylation sites, no notable protein motifs could be discerned. Hydropathy analysis (Kyte and Doolittle 1982) revealed abundant hydrophilic regions but no apparent transmembrane regions.

\section{Transcriptional arrest in jmj homozygotes}

We also examined the transcriptional status of the $i m j$ gene in homozygous embryos. Figure 9A shows the results of Northern blot analysis of RNA derived from E12.5 embryos of three genotypes. With a probe corresponding to sequences upstream of the fusion site $15^{\prime}$ probe), a single band of $\sim 6 \mathrm{~kb}$ was detected in all three genotypes. With the lac $Z$ gene as a probe, a band of $\sim 6$ $\mathrm{kb}$ was again noted both in heterozygotes and homozygotes. It is likely that the transcript from the trapped 


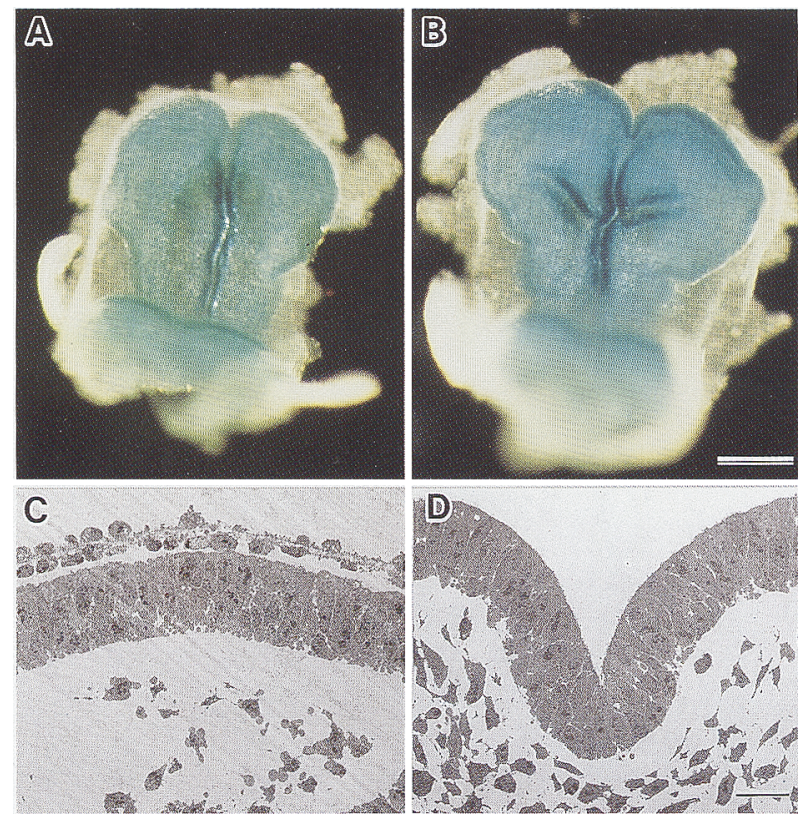

Figure 5. Abnormal groove formation on neural plate at E8 10 somite stage). $(A, B)$ Bright-field microscopy of dorsal view. $(A)$ heterozygote; $(B)$ homozygote, a littermate of $A$. Scale bar, 200 $\mu \mathrm{m}$. $(C, D)$ Transmission electron micrographs of parasagittal section of $A$ and $B$, respectively. Scale bar, $20 \mu \mathrm{m}$.

allele is slightly larger in size than that from the wildtype allele (Fig. 9A, lanes 1,3), but because the difference is too small to be resolved under the conditions of electrophoresis, a broader band is seen in RNA from heterozygotes (Fig. 9A, lane 2). When a sequence corresponding to the region downstream of the fusion site $13^{\prime}$ probe) was used as a probe, no signal appeared in homozygous embryos, but a positive signal, corresponding in size to that of wild-type RNA probed with the $5^{\prime}$ sequence, was detected in both wild type and heterozygotes (Fig. 9A, lanes 4-6). These results provide evidence that the $i m j$ gene is transcriptionally arrested in $i m j$ homozygous embryos. Experiments with reverse transcriptase followed by PCR (RT-PCR) (Mullis and Faloona 1987) supported the above observations (data not shown).

\section{The jmi gene is conserved among vertebrates}

Because neural tube closure is crucial for the formation of the central nervous system among vertebrates, we were prompted to see the general occurrence of the $i m j$ gene in the animal kingdom. DNA from all possible sources was probed with $j m i$ cDNA. As seen in Figure 9B, positive signals were detected in DNA of all vertebrates but not in any of the invertebrates examined thus far. This result suggests simply that the $i m i$ gene functions in the process of neural tube formation in vertebrates.

\section{Coincidence of in situ localization of jmj $m R N A$ with lacZ expression}

Next, we addressed the question as to whether the X-gal staining pattern reflects expression of mRNA from the imi gene. We compared the X-gal staining pattern in E910 heterozygous embryos with the localization of the in situ signal of $i m j$ mRNA in wild-type embryos of the same developmental stage. In overall embryonic tissues, the in situ signals of $j m j$ mRNA coincided with the X-gal positive regions. This demonstrates that the $\mathrm{X}$-gal staining pattern accurately reflects that of mRNA expression from the $i m j$ gene. Figure 10 shows a typical expression pattern at the midbrain-hindbrain boundary in E10.

\section{Discussion}

\section{Etiology of NTD in jmi homozygotes}

NTDs are among the most common malformations, and numerous examples have been described as spontaneous or teratogen-induced mutations. Nevertheless, our understanding of the underlying causes, especially at the molecular level, is extremely limited. In this study 12 of 26 live $i m i$ homozygotes $(46.2 \%$ ) showed NTD at E10.514.5. The NTD apparently results from a failure of neural tube fusion at the posterior site of the forebrain (Fig. 7). The two neural folds of abnormal homozygotes appear to be unable to approach each other in this region,
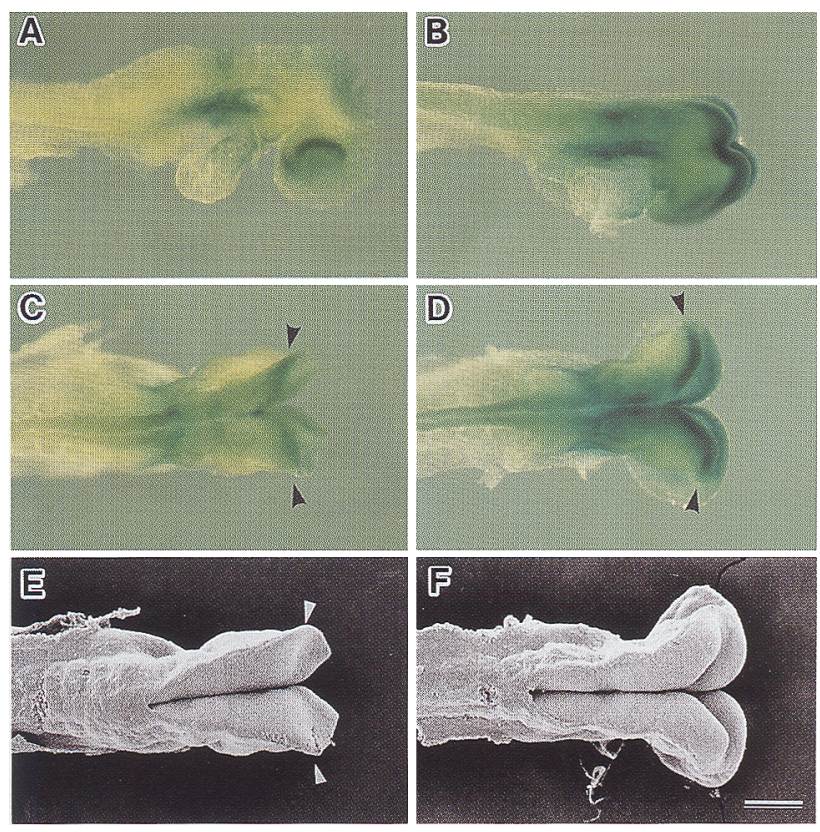

Figure 6. Abnormal groove formation on neural plate at E8.5 (nine-somite stage). $(A-D)$ Bright-field microscopy; $(E, F)$ scanning electron micrographs, $(A, B)$ Lateral view; $(C-F)$ dorsal view. $\{A, C, E\rangle$ Heterozygote; $(B, D, F)$ homozygote. Scale bar, 250 $\mu \mathrm{m}$. Arrowheads in $C$ and $E$ indicate $i m i-l a c Z$ expression and the future midbrain-hindbrain boundary, respectively. Arrowheads in $D$ mark corresponding regions in which $i m j-l a c Z$ is expressed in $C$. 

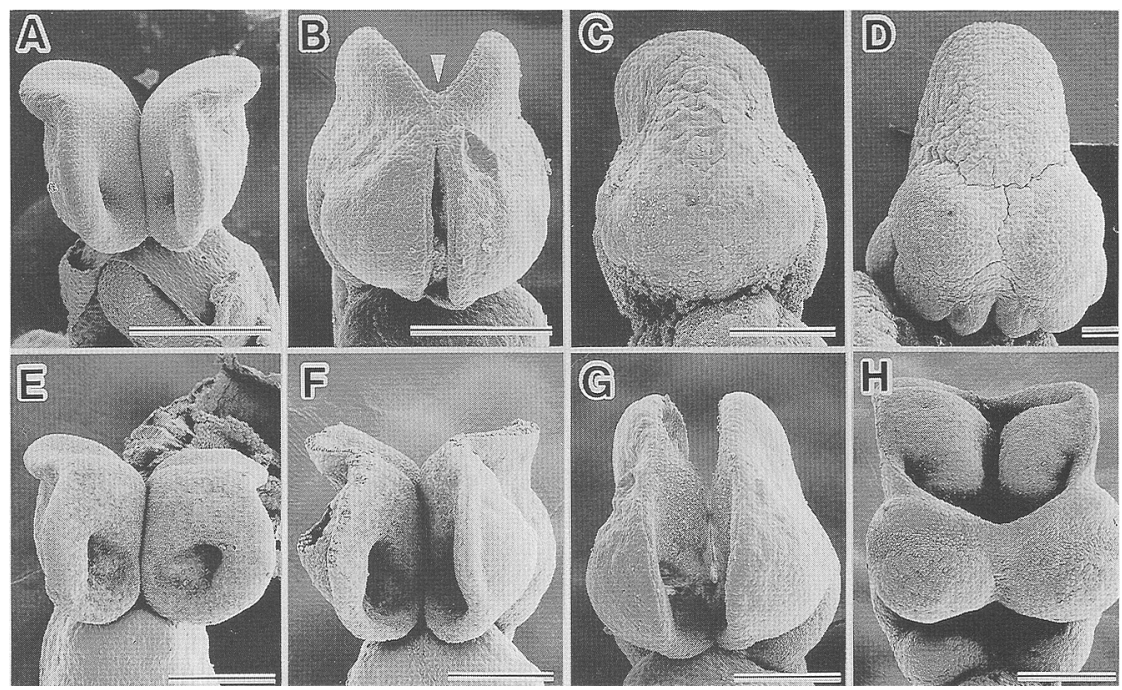

Figure 7. Head neural tube formation in heterozygotes and homozygotes. Scanning electron micrographs. $(A-D)$ heterozygote; $(E-H)$ homozygote. $(A, E)$ 10-somite stage; $(B, F)$ 12-somite stage; $(C, G)$ 15-somite stage; $(D, H) 21$-somite stage. Scale bar, 200 $\mu \mathrm{m}$. The arrowhead in $B$ marks the de novo fusion site in the posterior forebrain. thereby causing a defect in closure (Fig. 7E-H). Another abnormality was also observed: Approximately $40 \%$ of the homozygotes developed ectopic grooves and flexure of the neural plate at earlier stages, E8-8.5 (Figs. 5 and 6). One possibility is that abnormal groove formation in the head neural plate causes a flexure that prevents the normal bending required for closure, leaving the two neural folds far apart.
Although the link between NTD and abnormal morphology of the neural plate has not been proved, some mouse mutants, such as SELH (MacDonald et al. 1989) and trisomies 12 and 14 (Putz and Morris-Kay 1981), show midbrain exencephaly associated with abnormal morphology of the neural plate. In these mutants, the fusion at the posterior site of the forebrain is impaired. SELH mice have increased numbers of pyknotic cells in

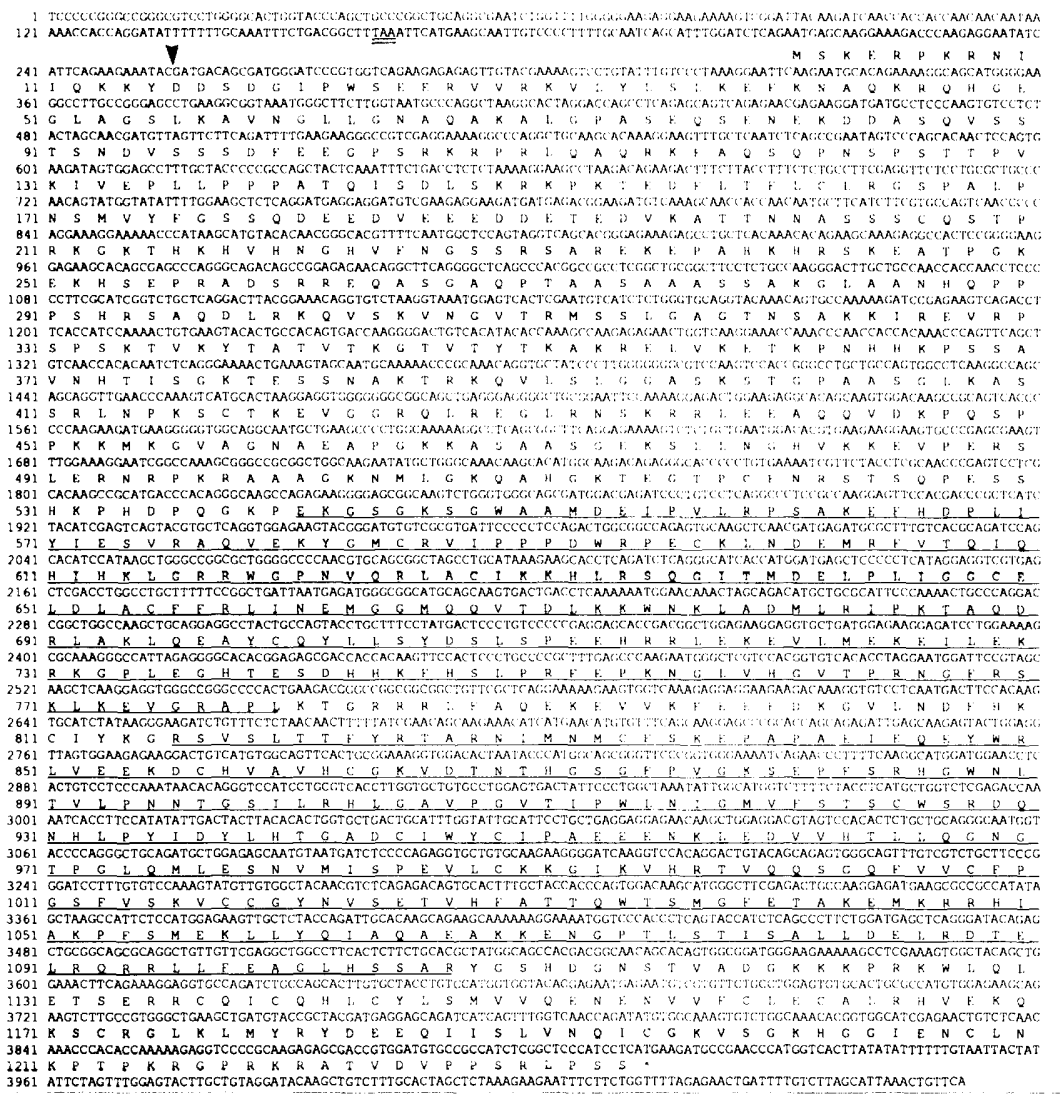

Figure 8. Nucleotide sequence and deduced amino acid sequence of $j m i$ cDNA. The arrowhead shows the fusion site between the $i m j$ cDNA and $n e o^{\mathrm{r}}$ of trap vector. TAA with double underline at position 160 is an in-frame stop codon located in the upstream region. Underlined amino acid sequences (amino acid positions 541-780 and 816-1107) are regions with significant homology to human RBP-2 and XE169 proteins (see text). 
Table 3. Sequence similarity of putative jmj protein

\begin{tabular}{llll}
\hline & $j m j$ & RBP-2 & XE169 \\
\hline$j m j$ & - & $27.9^{\mathrm{a}}(28.2)$ & $29.3^{\mathrm{a}}(33.6)$ \\
RBP-2 & $31.6^{\mathrm{b}}(54.8)$ & - & $57.7^{\mathrm{a}}(109.4)$ \\
XE169 & $31.9^{\mathrm{b}}(57.2)$ & $82.6^{\mathrm{b}}(153.6)$ & - \\
\hline
\end{tabular}

Numbers in parentheses are $z$ values.

aSimilarities $(\%)$ in region A (jmi, 541-780; RBP-2, 3-246; XE169, 4-243).

bSimilarities (\%) in region B (jmj, 816-1107; RPB-2, 359-657; XE169, 390-688).

the neuroepithelium and mesenchyme (MacDonald et al. 1989). In mice with trisomies 12 and 14, the edges of the neural plate fail to turn medially, preventing them from approaching each other (Putz and Morris-Kay 1981). This defect is associated with disruption of the neuroepithelial lamina, reduction of mesenchymal cell number, and an increased number of dead neuroepithelial cells (Morris-Kay and Putz 1986). We have not detected any significant abnormalities in neuroepithelial or mesenchymal cells in $i m j$ homozygotes (Fig. 5C,D). Determination of the cause of abnormal groove formation will require examination of the biological behavior of homozygous neuroepithelial cells such as proliferation, migration, and polarity. In view of the lack of knowledge concerning the genes responsible for SELH mouse and mouse trisomy 12 and 14 phenotypes, the $i m j$ mutant should provide a useful alternative model for investigating the etiology of midbrain exencephaly.

\section{Expression of the imi gene}

The expression of $j m j-l a c Z$ can be viewed as having some implications regarding neural development. Strong expression of $j m i-l a c Z$ was detected at the midbrainhindbrain boundary and in the cerebellum (Fig. 2). Because cells in the caudal region of the midbrain vesicle migrate into the cerebellum (Martinez and AlvaradoMallart 1989; Hallonet et al. 1990), it is possible that cells at the midbrain-hindbrain boundary migrate into the cerebellum and remain X-gal positive. However, it is known that cells from the midbrain migrate into the rostoromedial cerebellum (Martinez and Alvarado-Mallart 1989; Hallonet et al. 1990), and X-gal positive cells of $i m j$ heterozygotes were first detected in the lateral region (Fig. 2C). These observations suggest that the lacZ expression at the midbrain-hindbrain boundary is independent from that observed in the cerebellum.

Although one can imagine specific roles for the $j \mathrm{~m} j$ gene in the cerebellum before and after birth because of the strong expression of $i m j-l a c Z$, experimental analysis is complicated by homozygous lethality.

\section{Penetrance of the phenotype of jmj homozygotes}

All $i m i$ homozygotes died in utero, but incomplete penetrance was observed in NTD and abnormal groove formation (Table 2). Incomplete penetrance has often been observed in spontaneous mouse mutants with NTD (Copp et al. 1990). In the case of curly tail, only $1-3 \%$ of the homozygotes show exencephaly. One of the most attractive explanations for incomplete penetrance of $j m j$ phenotypes involves the heterogeneous genetic background of the homozygotes. In our experiments homozygotes were obtained from heterozygous parents that were hybrids between 129/Ola and Balb/cA. Backcross matings are in progress and a definitive estimate of the frequency of penetrance remains to be determined.

\section{Is the jmi gene responsible for the imj phenotype?}

All of the available evidence is consistent with the idea that the $j m j$ gene is responsible for the $j m j$ mutant phe-

\section{A}

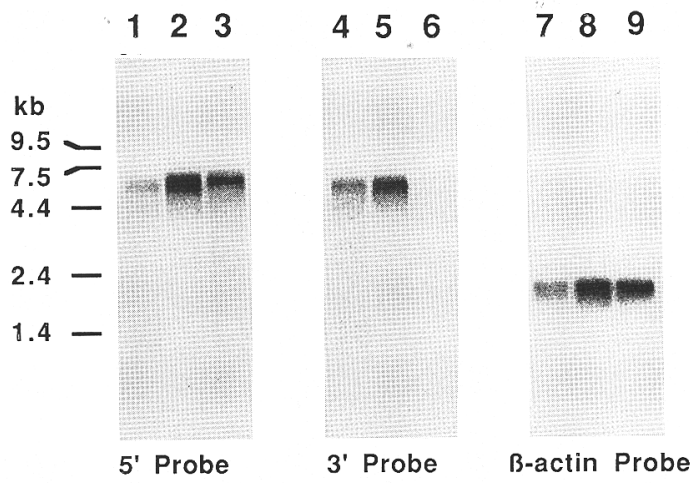

B

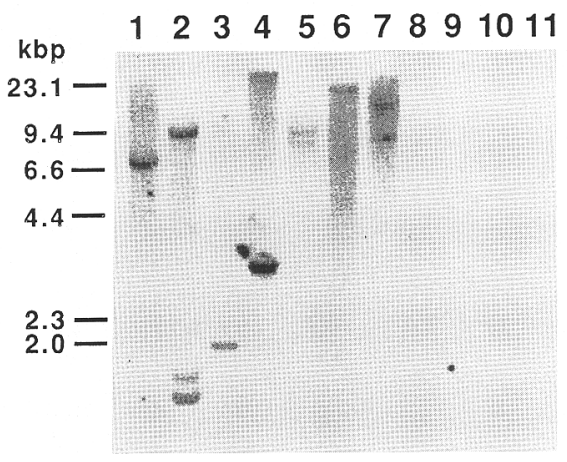

Figure 9. Northern blot and zoo blot analyses. (A) Northern blots. Two micrograms of poly $(A)^{+}$RNA from E12.5 embryos were electrophoresed. (Lanes 1,4,7) Wild type; (lanes 2,5,8) heterozygote $;($ lanes $3,6,9)$ homozygote. Probes 5 ' and 3 ' correspond to sequences upstream and downstream of the fusion site, respectively. Human $\beta$-actin cDNA was used as a control probe. $(B)$ Zoo blots. The blots contain DNAs (each $8 \mu \mathrm{g}$ ) from different organisms digested with EcoRI and electrophoresed. (Lane 1) Human (Homo sapiens); (lane 2) cow (Bovis domesticus); (lane 3) mouse (Mus musculus); (lane 4) chick (Gallus domesticus); (lane 5) frog (Xenopus laevis); (lane 6) snake (Rhineura floridiana); (lane 7) fish (Tautoga onitis); (lane 8) mussel (Mytilus edulis); (lane 9) fruit fly (Drosophila melanogaster); (lane 10) nematode (Caenorhabditis elegans); (lane 11) yeast (Saccharomyces cerevisiae). 


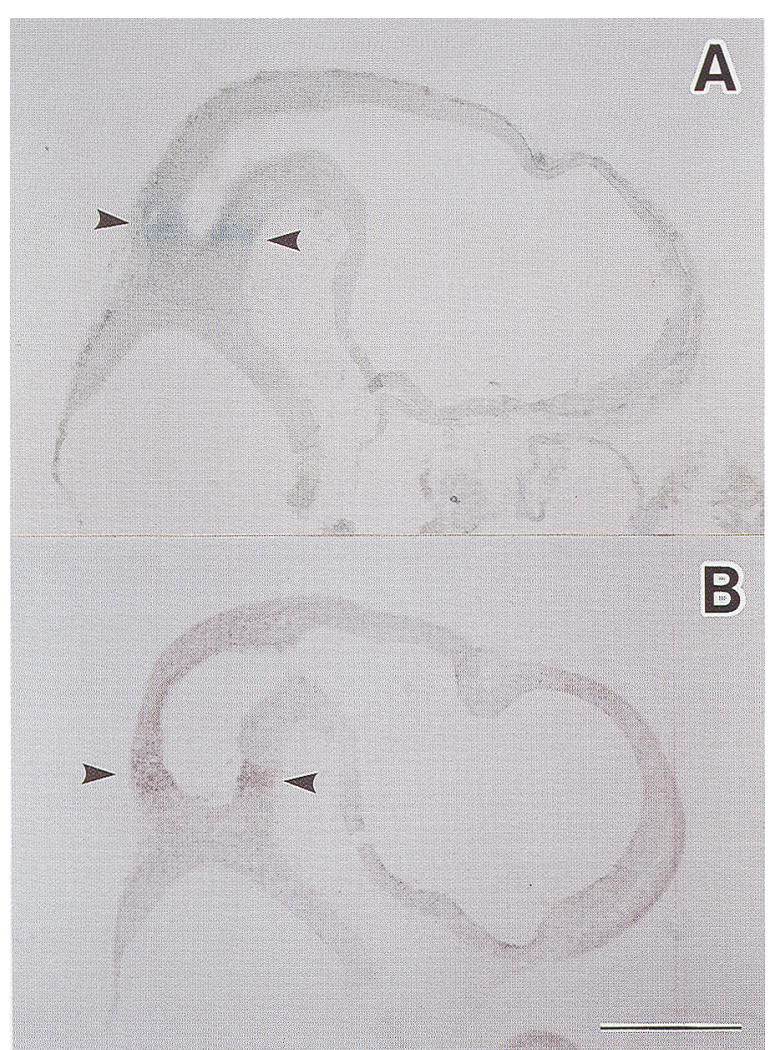

Figure 10. X-gal staining and the expression pattern of $i m j$ mRNA . Parasagittal section of E10 embryos. $|A| \mathrm{X}$-gal staining in $i m j$ heterozygote. $(B)$ In situ hybridization pattern of $i m j$ mRNA in wild-type embryo. Note that the in situ localization signal of $i m j$ mRNA at midbrain-hindbrain boundary (arrowheads in $B$ ) coincides with the pattern of $\mathrm{X}$-gal staining (arrowheads in $A$ ). Scale bar, $500 \mu \mathrm{m}$.

notype. The major reasons are as follows. (1) No intact im $j$ transcript was detected in homozygous embryos (Fig. 9A). Because of vector insertion into the trapped allele, transcription yielded a fusion mRNA that has a capacity to code for an anomalous protein, and only the aminoterminal 15 amino acids are identical to those of the wild-type protein (Fig. 8). (2) The affected region in homozygous embryos coincided with the lacZ-expressing region, that is, the region expressing the $i m i$ gene. Abnormal grooves were observed just anterior to the midbrain-hindbrain boundary where $l a c Z$ was expressed (Fig. 6C,D). Regarding the NTD, this abnormality may have resulted from abnormal grooves. (3) imi phenotypes were found only in homozygous mice and, as such, were trapped allele dependent (Tables 1 and 2). In addition, homozygotes derived from $\mathrm{F}_{5}$ heterozygotes, produced by backcross matings of $j m j$ heterozygotes to Balb/cA mice (statistically $96.9 \%$ of the genome is composed of the that of the Balb/cA mousel, showed the NTD as detected in $F_{1}$. This result excludes the possibility that mutations at other loci, except for those located close to the $i m j$ gene, are responsible for $j m i$ phenotypes. (4) The trap vector was integrated into a long intron $(>20 \mathrm{~kb})$.
However, Southern blot or PCR analyses showed neither deletion nor rearrangement of $>2 \mathrm{~kb}$ around the insertion site (data not shown). This observation favors the idea that no appreciable alteration in sequence has occurred in the proximity of the $i m i$ gene. Finally, it appears unlikely that $\beta$-galactosidase produced from the trap vector plays a role in generating the $j m j$ phenotypes, because heterozygous mice were apparently normal in our experiments. A previous report from another laboratory also argues against this possibility (Mansour et al. 1993). In addition, targeting $\beta$-galactosidase to the nucleus possibly reduced the deleterious effect of $\beta$-galactosidase on embryonic development (Kimura et al. 1994). They showed that germ-line transmission in transgenic mice was improved by targeting $\beta$-galactosidase to the nucleus.

Unequivocal proof would require a rescue experiment such as transgenesis with the intact imi gene or producing the same phenotypes by $i m j$ gene targeting.

\section{The putative jmj protein}

The putative imj protein has two regions (A and B) of significant homology to RBP-2 and the XE169 protein (Table 3). RBP-2 is a member of a group of proteins that bind to the retinoblastoma gene product (RB) through a sequence-conserved binding motif composed of a short stretch of amino acids (Defeo-Jones et al. 1991). Because the conserved binding motif of RBP-2 could not be found in XE169 protein or in the putative $j m i$ protein, it is not known whether these gene products have a capacity to bind RB protein. Although the physiological function of these three proteins is not known, homologies among their sequences suggest that RBP-2, XE169, and the $i m j$ genes belong to the same family and that regions $A$ and B may serve as a distinctive motif recognizing its members. Further studies of the $i m i$ protein, as well as the RBP-2 and XE169 protein, including use of specific antibodies, may provide a basis for understanding the functions of the $j m i$ gene and etiology of $j m i$ phenotypes during development of the nervous system.

\section{Materials and methods}

\section{Cells and cell culture}

ES cell line E14 derived from 129/Ola mouse was a gift from M.L. Hooper (Edinburgh University, UK). Culture of a parent line and trapped lines were carried out according to Robertson (1987).

\section{Construction of the trap vector}

Trap vector TV2 (Fig. 1A) was constructed from the following DNA fragments: (1) XbaI-BamHI fragment containing a splicing acceptor site of the mouse zinc finger gene $Z f p 40$ (Noce et al. 1992), (2) Escherichia coli lacZ gene, (3) E. coli neo ${ }^{x}$ gene, (4) IRES derived from encephalomyocarditis virus (a gift from E. Wimmer, State University of New York, Stony Brook), (5) oligonucleotide representing the nuclear transporting signal of SV40 large $T$ antigen (a gift from $M$. Tanaka, Mitsubishi Kasei Institute of Life Sciences, Japan), (8) E. coli supF tRNA gene, (9) pBluescript (Stratagene). 


\section{Electroporation and drug selection}

Trypsinized ES cells were washed in culture medium and suspended in phosphate-buffered saline (PBS). The cell suspension was placed in an electroporation cuvette, mixed with trap vector DNA linearized with BgIII at a concentration of $25 \mu \mathrm{g} / \mathrm{ml}$, and electroporated at $200 \mathrm{~V}, 500 \mu \mathrm{F}$, and plated on dishes. After 2 days, G418 was added at $250 \mu \mathrm{g} / \mathrm{ml}$ to the culture, and surviving colonies were picked up after another 7-10 days.

\section{Blastocyst injection and animal breeding}

Blastocyst injection was performed according to Robertson (1987). Blastocysts were recovered from the mating of C57BL/ 10 SnSlc (Japan SLC, Inc.) to C57BL / 6 NCri /Charles River Japan Inc.) mice. ES cell-injected blastocysts were transferred into the uterus of pseudopregnant $\mathrm{F}_{1}(\mathrm{C} 57 \mathrm{BL} / 10 \times \mathrm{C} 57 \mathrm{BL} / 6)$ mice. Male chimeras were bred with Balb/cA Icl females (Clea Japan, Inc.) to test for germ-line transmission of the dominant chinchilla coat marker. $F_{1}(\mathrm{Balb} / \mathrm{cA} \times 129 / \mathrm{Ola})$ mice heterozygous for the imi trapped allele were intercrossed to produce homozygotes. Noon of the day that a vaginal plug was detected was defined as E0.5, upon which gestational age was assigned. All mice were caged in a lighted room (12 hr of light and $12 \mathrm{hr}$ of darkness) with free access to water and standard mouse diet.

\section{$X$-gal staining}

Cultured cells were fixed for $3 \mathrm{~min}$ at room temperature in $0.2 \%$ glutaraldehyde in PBS. Embryos were fixed for $20-30 \mathrm{~min}$ at $4^{\circ} \mathrm{C}$ in $0.2 \%$ glutaraldehyde, $1 \%$ formaldehyde, and $0.02 \% \mathrm{NP}-40$ in PBS. Fixed cells and embryos were washed at room temperature for $15 \mathrm{~min}$ in buffer $\left(2 \mathrm{mM} \mathrm{MgCl}{ }_{2}, 0.02 \% \mathrm{NP}-40,0.01 \%\right.$ deoxycholate in PBS| three times. Then they were stained either overnight or for several hours at $37^{\circ} \mathrm{C}$ in $0.1 \%$ 4-chloro-5bromo-3-indolyl- $\beta$-D-galactopyranoside (X-gal, Nova Biochem), $5 \mathrm{mM} \mathrm{K}_{3} \mathrm{Fe}(\mathrm{CN})_{6}, 5 \mathrm{~mm} \mathrm{~K}{ }_{4} \mathrm{Fe}(\mathrm{CN})_{6}$ in the same buffer. After staining, embryos were washed in PBS and postfixed in $2 \% \mathrm{gl}$ utaraldehyde in PBS.

\section{Transmission and scanning electron microscopy}

Embryos were fixed in $2 \%$ glutaraldehyde in PBS for $1 \mathrm{hr}$ at $4{ }^{\circ} \mathrm{C}$, washed several times in PBS, postfixed in $1 \%$ osmium tetroxide in $0.1 \mathrm{M}$ phosphate buffer $\left(\mathrm{pH} \mathrm{7.4)}\right.$ for $1 \mathrm{hr}$ at $4^{\circ} \mathrm{C}$, and then dehydrated in graded series of ethanol. For transmission electron microscopy, the embryos were embedded in Epock 812 (Oken Co., Tokyo). Sections were cut with a Sorvall MT-1 ultramicrotome and were doubly stained in uranyl acetate and lead acetate. Thin sections were examined with a JEOL $1200 \mathrm{EX}$ electron microscope. For scanning electron microscopy, the fixed embryos were immersed in a critical-point dryer (Hitachi HCP-1). After ionized gold coating, the specimens were examined with a Hitachi S-800 scanning electron microscope.

\section{PCR}

All PCR experiments were performed under the following temperature cycling conditions with a Program Temp Control System (Astec): $94^{\circ} \mathrm{C}$ for $1 \mathrm{~min}$, at $60^{\circ} \mathrm{C}$ for $2 \mathrm{~min}$, at $72^{\circ} \mathrm{C}$ for $3 \mathrm{~min}$ for 35 cycles. The PCR mixture consisted of $50 \mathrm{mM} \mathrm{KCl}, 10 \mathrm{mM}$ Tris- $\mathrm{HCl}(\mathrm{pH} 9.0), 0.1 \%$ Triton X-100, $1.5 \mathrm{~mm} \mathrm{MgCl} 2,0.2 \mathrm{~mm}$ each of the dNTPs, $0.4 \mu \mathrm{m}$ each of primers and 0.025 units/ $\mu$ lof Taq DNA polymerase (Promega).

\section{Cloning of genomic DNA flanking vector insertion site}

Genomic DNA of B6 ES cells was digested with BamHI and ligated to a BamHI adapter (Takara Shuzo, Japan). Fragments containing the $5^{\prime}$ region of the trap vector insertion site were PCR amplified with primers in the adapter $\left(5^{\prime}\right.$-GTACATATTGTCGTTAGAACGCG- $\left.3^{\prime}\right)$ and in the $n e o^{\mathrm{r}}$ gene $\left(5^{\prime}\right.$-TCTGTTGTGCCCAGTCATAG- $\left.3^{\prime}\right)$. Using this fragment as a probe, a $16-\mathrm{kb}$ fragment was cloned from a mouse genomic DNA library (a gift from M. Taniguchi, Chiba University, Japan) as described in Maniatis et al. (1989).

\section{Allele-specific genotyping}

DNA from yolk sac of embryos or from the tails of pups was purified according to Maniatis et al. (1989) for genomic Southern blot or according to Singer-Sam et al. (1990) for PCR. Two pairs of oligonucleotides that recognize the wild-type allele of the $i m i$ gene (primer P1, 5'-ACAGGCATGTGCCATCATAC$3^{\prime}$, and P2, 5'-TTGAGCA-GCTGTGCTCACAA-3') or the trapped allele (primer V1, 5'-CTGCAAGATGTATGGGAGTG$3^{\prime}$, and V2, 5'-GTCCAGATCATCCTGATCGACA-3') were used in the same PCR reaction (see Fig. 1B). Amplified products were analyzed by electrophoresis on agarose gels using ethidium bromide staining. Embryos were scored as wild type (positive with only primers $\mathrm{P} 1$ and $\mathrm{P} 2$ ), heterozygous (positive with both primer pairs), or homozygous (positive with only primers $\mathrm{V} 1$ and $\mathrm{V} 2$ ) (Fig. 1C).

\section{5' RACE and CDNA walking}

To obtain the fragment of $j m i$ cDNA, we used a $5^{\prime}$-Ampli Finder RACE Kit (Clontech). Briefly, first-strand cDNA was synthesized with a primer within neor gene of TV2 $\left(5^{\prime}\right.$-GTCCAGATCATCCTGATCGACA-3'). After hydrolysis of RNA with $\mathrm{NaOH}$, anchor DNA was ligated to the first strand CDNA with T4 RNA ligase. Then, fragments were amplified by PCR with a primer containing a sequence complementary to the anchor DNA $15^{\prime}$-CTGGTTCGGCCCACCTCTGAAGGTTCCAGAATTCGATAG-3') and a nested TV2 specific primer $\left(5^{\prime}\right.$-TCTGTTGTGCCCAGTCATAG-3'). The downstream cDNA fragment was isolated from ES cell cDNA ligated to $\lambda Z A P$ II arms (Stratagene) by PCR using a primer corresponding to the sequence in the fragment obtained by $5^{\prime}$ RACE $\left(5^{\prime}\right.$-GTCCCCTTTTGCAATCA-3') and T3 primer (5'-ATTAACCCTCACTAAAG$\left.3^{\prime}\right)$. The latter primer is specific for the sequence in the multicloning region of $\lambda$ ZAP II. To obtain further downstream regions, this procedure was successively repeated three times. Amplified product was cloned into a pGEM-T plasmid (Promega). DNA sequencing analyses were carried out by the dideoxy chain-termination method using a BcaBEST sequencing kit (Takara Shuzo).

\section{Southern and Northern blots}

RNA purification as well as Southern and Northern blot analyses were carried out according to Noce et al. (1992). For the zoo blot, a membrane of EVO selectable set kit (BIOS) was hybridized at $32^{\circ} \mathrm{C}$ overnight and washed three times in $2 \times$ SSC, $0.1 \%$ SDS, for $15 \mathrm{~min}$ at $45^{\circ} \mathrm{C}$. The $5^{\prime}$ and $3^{\prime}$ probes for the Northern blot correspond to nucleotide positions 1-255 and 269-561, and the probe for the zoo blot corresponds to nucleotide positions 178-1567 of imi cDNA (Fig. 8), respectively.

\section{In situ hybridization}

imi sense and antisense single-stranded RNA probes were synthesized using the PCR clone corresponding to nucleotide po- 
sition $178-1370$ as a template. Plasmid containing the insert, flanked by T7 and SP6 promoters (pGEM-T, Promega), was linearized and transcribed with T7 or SP6 RNA polymerase in the presence of digoxigenin-UTP (Boehringer Mannheim). Probes were diluted to $1 \mu \mathrm{g} / \mathrm{ml}$ in hybridization mixture. Hybridization to frozen sections and washing steps were performed as described by Wilkinson et al. (1987). Sections were examined and photographed using a Zeiss Axiophot microscope.

\section{Acknowledgments}

We thank Drs. Martin L. Hooper for the gift of the E14 ES cell line, Eckard Wimmer for IRES DNA, Masato Tanaka for lacZ with the nuclear transporting sequence, Masaru Taniguchi for the mouse genomic library, and Michihiko Ito for technical advice regarding the construction of the cDNA library. We also thank Mr. Nobuyuki Nakajima and Mr. Toru Yao for computer analyses of predicted proteins and Drs. Hirokazu Fujimoto and Robert A. Shiurba for thoughtful discussions and critical reviews of the manuscript. This work was partially supported by a research grant from the Ministry of Education, Science, and Culture of Japan.

The publication costs of this article were defrayed in part by payment of page charges. This article must therefore be hereby marked "advertisement" in accordance with 18 USC section 1734 solely to indicate this fact.

\section{Note}

The nucleotide sequence data reported in this paper will appear in the DNA Data Bank of Japan, EMBL, and National Center for Biology Information nucleotide sequence data bases under accession number D31967.

\section{References}

Agulnik, A.I., M.J. Mitchell, J.L. Lerner, D.R. Woods, and C.E. Bishop. 1994a. A mouse Y chromosome gene encoded by a region essential for spermatogenesis and expression of malespecific minor histocompatibility antigens. Hum. Mol. Genet. 3: 873-878.

Agulnik, A.I., M.J. Mitchell, M.-G. Mattel, G. Borsani, P.A. Avner, J.L. Lerner, and C.E. Bishop. 1994b. A novel X gene with a widely transcribed Y-linked homologue escapes X-inactivation in mouse and human. Hum. Mol. Genet. 3: 879884.

Chen, Z., G.A. Friedrich, and P. Soriano. 1994. Transcriptional enhancer factor 1 disruption by a retroviral gene trap leads to heart defects and embryonic lethality in mice. Genes \& Dev. 8: 2293-2301.

Copp A.J., F.A. Brook, J.P. Estibeiro, A.S.W. Shum, and D.L. Cockroft. 1990. The embryonic development of mammalian neural tube defects. Prog. Neurobiol. 35: 363-403.

Defeo-Jones, D., P.S. Huang, R.E. Jones, K.M. Haskell, G.A. Vuocolo, M.G. Hanobik, H.E. Huber, and A. Oliff. 1991. Cloning of cDNAs for cellular proteins that bind to the retinoblastoma gene product. Nature 352: 251-254.

DeGregori, J., A. Russ, H. von Melchner, H. Rayburn, P. Priyaranjan, N.A. Jenkins, N.G. Copeland, and H.E. Ruley. 1994. A murine homolog of the yeast RNAl gene is required for postimplantation development. Genes \& Dev. 8: 265276.

Fattaey, A.R., K. Helin, M.S. Dembski, N. Dyson, E. Harlow, G.A. Vuocolo, M.G. Hanobik, K.M. Haskell, A. Oliff, D. Defeo-Jones, and R.E. Jones. 1993. Characterization of the ret- inoblastoma binding proteins $\mathrm{RBP} 1$ and $\mathrm{RBP} 2$. Oncogene 8: 3149-3156.

Friedrich, G. and P. Soriano. 1991. Promoter traps in embryonic stem cells: A genetic screen to identify and mutate developmental genes in mice. Genes \& Dev. 5: 1513-1523.

Frohman, M.A., M.K. Dush, and G.R. Martin. 1988. Rapid production of full-length cDNAs from rare transcripts: Amplification using a single gene-specific oligonucleotide primer. Proc. Nat1. Acad. Sci. 85: 8998-9002.

Gossler, A., A.L. Joyner, J. Rossant, and W.C. Skarnes. 1989. Mouse embryonic stem cells and reporter constructs to detect developmentally regulated genes. Science 244: 463-465.

Hallonet, M.R., M.-A. Teillet, and N.M. Le Douarin. 1990. A new approach to the development of the cerebellum provided by the quail-chick marker system. Development 108: 19-31.

Jang, S.K., H.-G. Kräusslich, M.J. H. Nicklin, G.M. Duke, A.C. Palmenberg, and E. Wimmer. 1988. A segment of the 5 ' nontranslated region of encephalomyocarditis virus RNA directs internal entry of ribosomes during in vitro translation. $J$. Virol. 62: 2636-2643.

Kim, D.G., H.M. Kang, S.K. Jang, and H.-S. Shin. 1992. Construction of a bifunctional mRNA in the mouse by using the internal ribosomal entry site of the encephalomyocarditis virus. Mol. Cell. Biol. 12: 3636-3643.

Kimura, S., H. Niwa, M. Moriyama, K. Araki, K. Abe, T. Miike, and $\mathrm{K}$. Yamamura. 1994. Improvement of germ line transmision by targeting $\beta$-galactosidase to the nuclei in transgenic mice. Dev. Growth Differ. 36: 521-527.

Kozak, M. 1991. Structural features in eukaryotic mRNAs that modulate the initiation of translation. 1. Biol. Chem. 266: 19867-19870.

Kyte, J. and R.F. Doolittle. 1982. A simple method for displaying the hydropathic character of a protein. I. Mol. Biol. 157: 105132.

Lipman, D.J. and W.R. Pearson. 1985. Rapid and sensitive protein similarity searches. Science 227: 1435-1441.

MacDonald, K.B., D.M. Juriloff, and M.J. Harris. 1989. Developmental study of neural tube closure in a mouse stock with a high incidence of exencephaly. Teratology 39: 195-213.

Maniatis, T., E.F. Fritsch, and J. Sambrook. 1989. Molecular cloning: A laboratory manual. Cold Spring Harbor Laboratory Press. Cold Spring Harbor, New York.

Mansour, S.L., J.M. Goddard, and M.R. Capecchi. 1993. Mice homozygous for a targeted disruption of the proto-oncogene int-2 have developmental defects in the tail and inner ear. Development 117: 13-28.

Martinez, S. and R.M. Alvardo-Mallart. 1989. Rostral cerebellum originates from the caudal portion of the so-called "mesencephalic" vesicle: A study using chick-quail chimeras. Eur. J. Neurosci. 1: 549-560.

Morriss-Kay, G.M. and B. Putz. 1986. Abnormal neural fold development in mouse trisomy 12 and trisomy 14. II. LM and TEM. Brain Res. Bull. 16: 825-832.

Mullis, K.B. and F.A. Faloona. 1987. Specific synthesis of DNA in vitro via a polymerase-chain reaction. Methods Enzymol. 155: 335-350.

Noce, T., Y. Fujiwara, M. Ito, T. Takeuchi, N. Hashimoto, M. Yamanouchi, T. Higashinakagawa, and H. Fujimoto. 1992. A novel murine zinc finger gene mapped within the $t^{\text {w18 }}$ deletion region expresses in germ cells and embryonic nervous system. Dev. Biol. 155: 409-422.

Putz, B. and G. Morriss-Kay. 1981. Abnormal neural fold development in trisomy 12 and trisomy 14 mouse embryos. I. Scanning electron microscopy. J. Embryol. Exp. Morphol. 66: 141-158. 


\section{Takeuchi et al.}

Robertson, E.J. 1987. Embryo-derived stem cell lines. In Teratocarcinomas and embryonic stem cells: A practical approach (ed. E.J. Robertson), pp. 71-112. IRL Press, Oxford, UK.

Sakai, Y. 1989. Neurulation in the mouse: Manner and timing of neural tube closure. Anat. Rec. 223: 194-203.

Singer-Sam, J., J.M. LeBon, R.L. Tanguay, and A.D. Riggs. 1990. A quantitative HpaII-PCR assay to measure methylation of DNA from a small number of cells. Nucleic Acids Res. 18: 687.

Skarnes, W.C., B.A. Auerbach, and A.L. Joyner. 1992. A gene trap approach in mouse embryonic stem cells: The lacZ reporter is activated by splicing, reflects endogenous gene expression, and is mutagenic in mice. Genes \& Dev. 6: 903918.

Wilkinson, D.G., J.A. Bailes, and A.P. McMahon. 1987. Expression of the proto-oncogene int-1 is restricted to specific neural cells in the developing mouse embryo. Cell 50: 79-88.

Wu, J., J. Ellison, E. Salido, P. Yen, T. Mohandas, and L.J. Shapiro. 1994. Isolation and characterization of XE169, a novel human gene that escapes X-inactivation. Hum. Mol. Genet. 3: $153-160$. 


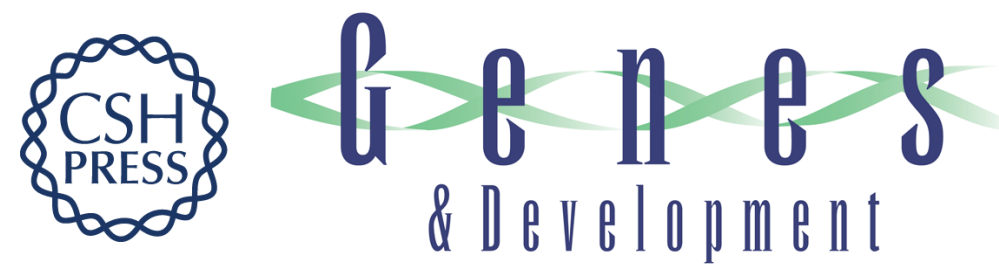

\section{Gene trap capture of a novel mouse gene, jumonji, required for neural tube formation.}

T Takeuchi, Y Yamazaki, Y Katoh-Fukui, et al.

Genes Dev. 1995, 9:

Access the most recent version at doi:10.1101/gad.9.10.1211

References This article cites 29 articles, 12 of which can be accessed free at:

http://genesdev.cshlp.org/content/9/10/1211.full.html\#ref-list-1

License

Email Alerting Receive free email alerts when new articles cite this article - sign up in the box at the top Service right corner of the article or click here.

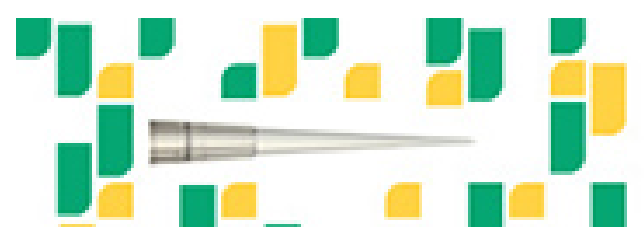

Focused on your science.

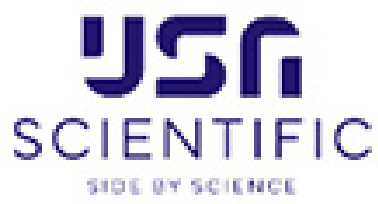

Copyright (c) Cold Spring Harbor Laboratory Press 